Research article

\title{
EXPRESSION OF E2 (gp 55) GLYCOPROTEIN OF CLASSICAL SWINE FEVER VIRUS IN LYMPHOID TISSUE AND BRAIN OF EXPERIMENTALLY INFECTED PIGLETS WITH DIFFERENT IMMUNOLOGICAL STATUS
}

\author{
POLAČEK Vladimir ${ }^{*}$, PRODANOV-RADULOVIĆ Jasna ${ }^{1}$, DOŠEN Radoslav ${ }^{1}$, \\ PETROVIĆ Tamaš ${ }^{1}$, BECSKEI Zsolt ${ }^{2}$, ALEKSIĆ-KOVAČEVIĆ Sanja ${ }^{3}$
}

${ }^{1}$ Scientific Veterinary Institute „Novi Sad”, Novi Sad, Serbia, ${ }^{2}$ Department for Animal Breeding, Faculty of Veterinary Medicine, Belgrade, Serbia, ${ }^{3}$ Department of Pathology, Faculty of Veterinary Medicine, Belgrade, Serbia,

(Received 26 April; Accepted 29 May 2014)

Classical swine fever (CSF) is a highly contagious viral disease of domestic swine and wild boars. The aim of the study was to examine samples of lymphoid tissues and brain for the presence of Classical Swine Fever Virus (CSFV) antigen in piglets that originate from vaccinated and unvaccinated sows, in order to compare the intensity of pathological lesions in conditions of different immunological status. A total of 20 crossbreed piglets of both sexes, aged 45 days were divided in three groups (G1, G2 and G3). Piglets of G1 originated from sows vaccinated with a live vaccine containing attenuated C strain CSFV. Piglets of G2 originated from unvaccinated sows. Two piglets of $\mathrm{G} 3$ originated from vaccinated and two piglets from unvaccinated sows and they served as the control group. All the piglets from G1 and G2 were intramuscularly inoculated with $2 \times 10^{5} \mathrm{TCDI} /{ }_{50}$ of CSFV, Baker strain and they died by the $22^{\text {nd }}$ day post inoculation. Immunohistochemistry was applied for immunolabeling E2 (gp55) glycoprotein of CSFV in the tonsils, mandibular lymph nodes, ileocecal valve and brain of all tested piglets. Differences were observed in the severity of lesions in the lymphoid tissue and the brain between G1 and G2 piglets. The present level of colostral antibodies was not able to protect piglets in G1 from the fatal outcome of the disease. Among others, this finding may also have an impact on vaccination policy in the future. Having in mind that vaccination of all domestic pigs with attenuated $\mathrm{C}$-strain vaccine is still a mandatory control measure for CSF in Serbia, soon a non-vaccination policy should be harmonized with EU directives.

Key words: classical swine fever, E2 (gp55), immunohistochemistry

\section{INTRODUCTION}

Classical swine fever (CSF) is a highly contagious viral disease of domestic swine and wild boars. The causative agent is the Classic Swine Fever Virus (CSFV)

\footnotetext{
* Corresponding author: e-mail: vlade@niv.ns.ac.rs
} 
that belongs to the genus Pestivirus of the Flaviviridae family [1-3]. CSF has severe consequences on animal welfare, livestock production, trade and national economy [4]. During CSFV infection immunosupression reflected in depletion of lymphocytes in lymphoid organs occurs, while severe lymphopenia is present [5-10]. Lymphocytes, monocytes, immature granulocytes as well as endothelial cells, have been recognized to be infected with CSFV, consequently leading to morphological changes in various tissues [11]. Morphological lesions and lymphocyte depletion in different lymphoid tissues depend on the virulence of CSFV [12]. There are also other viruses in pigs that induce immunosupression. In pigs suffering from postweaning multisystemic wasting syndrome induced by Porcine Circo type 2 Virus (PCV2), lymphocyte depletion in lymphoid tissues is the most prominent finding [13]. In countries where CSFV has not been eradicated, a vaccination program with an attenuated live vaccine, mostly with $\mathrm{C}$ strain is established. In such circumstances colostral antibodies are expected to protect piglets up to a certain level. Having in mind that the last CSF outbreak in Serbia was in 2010, vaccination of all domestic pigs with C-strain vaccine is still a mandatory control measure $[14,15]$. The goal of the study was to examine samples of lymphoid tissues and brain for the presence of Classical Swine Fever Virus (CSFV) antigen in piglets that originate from vaccinated and unvaccinated sows, in order to compare the intensity of pathological lesions in conditions of different immunological status. Among others, these results are expected to have impact on non-vaccination policy, which should be harmonized with EU directives in Serbia in the future.

\section{MATERIALS AND METHODS}

\section{Animals, Virus and Experimental Design}

A total of 20 piglets of both sexes, aged 45 days were included in the study. The piglets (crossbreeds of Landrace and Large White) were divided into three groups. The first group (G1) consisted of 8 piglets originated from sows vaccinated with the live vaccine, containing the attenuated $C$ strain of Classical Swine Fever Virus (CSFV). In the serum of these piglets maternal anti-CSFV antibodies were present before the challenge. The second group (G2) consisted of 8 piglets, serologically negative for anti-CSFV antibodies, originated from unvaccinated sows. The control group (G3) was represented by four piglets, two piglets originated from vaccinated and two from unvaccinated sows. The animals were housed in the Experimental Diagnostic Centre of the Scientific Veterinary Institute "Novi Sad", Novi Sad, Serbia. The study has been conducted in full accordance with the Animal Welfare Act (Serbian Official Gazette, No 41/2009).

Health status of all pigs from G1 and G2 was monitored for 10 days prior to intramuscular inoculation with $2 \times 10^{5} \mathrm{TCDI} /{ }_{50}$ of CSFV, Baker strain. The control group piglets (G3) were intramuscularly inoculated with $1 \mathrm{ml}$ of phosphate buffered saline (PBS), $\mathrm{pH}$ 7.2. After virus inoculation clinical signs and rectal temperature were 
monitored daily. All experimentally infected piglets of G1 and G2 died by the $22^{\text {nd }}$ day after inoculation. Euthanasia of piglets of the G3-control group was performed on the $22^{\text {nd }}$ day after PBS inoculation, using intravenous injection of $0.5 \mathrm{ml} / \mathrm{kg}$ T61 (embutramide $200 \mathrm{mg} / \mathrm{ml}$; mebezonium iodide $50 \mathrm{mg} / \mathrm{ml}$; tetracaine hydrochloride $5 \mathrm{mg} / \mathrm{ml}$, Intervet, International) and proper premedication with $80 \mathrm{mg} / \mathrm{kg}$ azaperone (Stresnil, Janssen).

\section{Blood collection and specific antibody detection in the serum}

Blood samples were taken from the jugular vein from all piglets of G1, G2 and G3 in order to detect specific maternal antibodies for CSFV and Bovine Viral Diarrhoea Virus (BVDV). After centrifugation of blood samples at $1000 \mathrm{rpm}$ for 10 minutes, serum samples were tested for specific anti-CSFV antibodies with the IDEXX ${ }^{\circledR}$ Classical Swine Fever Virus Antibody Test Kit according to the manufacturer's instructions. Detection of specific anti-BVDV antibodies in the sera was performed by virus neutralization (VN) test with NADL strain, according to the procedure described in the Manual of Diagnostic Tests and Vaccines for Terrestrial Animals, Office International Des Epizooties (2012).

\section{Molecular detection of CSFV and PCV2}

Molecular detection of CSFV and PCV2 was carried out on lymphoid tissue (tonsils, mandibular lymph nodes and ileocoecal valves) of each piglet in G1, G2 and G3. Viral RNA of CSFV was extracted from the tissues using Trizol reagent (GIBCO BRL) according to manufacturer's instructions. Briefly, three volumes of Trizol reagent were added to $250 \mu \mathrm{l}$ of sample material (supernatant from $10 \%$ tissue homogenate in PBS). The extraction was performed sequentially with chloroform and isopropanol and RNA was precipitated with $80 \%$ ethanol prior to resuspension in DEPC treated water. The "one-tube" or "one-step RT-PCR" assay was performed using reagents supplied in a commercial "Access RT-PCR system" (Promega, USA). RT-PCR amplification was performed using E2 gene specific primers: gp55-U: 5'-ATA TAT GCT CAAGGGCGA GT-3' (sense, position in genome of the Alfort strain is 33783397); gp55-L: 5'-ACA GCA GTAGTATCC ATT TCTTTA-3' (antisense, position in the genome of the Alfort strain is $3685-3662)$. RNA sample $(6 \mu \mathrm{l})$ was added to the reaction mixtures $(44 \mu \mathrm{l})$ containing $A M V / T f 1 \times$ reaction buffer, dNTP mix $(10 \mathrm{mM}), 25 \mathrm{pmol}$ of sense and antisense primer, $1 \mathrm{mM}$ of $\mathrm{MgSO}_{4}, 5 \mathrm{U}$ of AMV RT and $5 \mathrm{U}$ of TfDDNA polymerase. The RT-PCR cycling conditions were as follows: 45 min at $48{ }^{\circ} \mathrm{C}$ for $\mathrm{RT}, 94^{\circ} \mathrm{C}$ for $2 \mathrm{~min}$ for AMV RT inactivation and RNA/cDNA/ primer denaturation, 40 cycles of $30 \mathrm{~s}$ at $94^{\circ} \mathrm{C}, 1 \mathrm{~min}$ at $60^{\circ} \mathrm{C}$ and $2 \mathrm{~min}$ at $68^{\circ} \mathrm{C}$, and a final extension step at $68^{\circ} \mathrm{C}$ for $7 \mathrm{~min}$. The amplified products were analyzed by electrophoresis on a $1.5 \%$ agarose gel.

In order to determine whether the piglets were infected with porcine circovirus type 2 (PCV2), PCR assay was carried out on the lymphoid tissue samples (tonsils, mandibular lymph nodes and ileocoecal valves). Extraction of total DNA from the lymphoid 
tissue samples was done with "QIAamp ${ }^{\circledR}$ DNA Mini Kit”, (Qiagen, Hilden, Germany) following manufacturer's instructions. For the amplification of $501 \mathrm{bp}$ fragment of ORF2 regions of the viral DNA, previously described PCV2 specific oligonucleotide primers PCV2-2A: 5'-CACCTTCGGATATACTGTCAA-3' (nucleotide position 1582-1562) and PCV2-2B: 5'-TACATGGTTACACGGATATTGTA-3' (nucleotide position 1082-1104) were used. PCR method was carried out according to the manufacturer's protocol modified by Becskei et al. [13].

\section{Histopathology and immunohistochemistry}

Tissue samples were taken from the mandibular lymph nodes, tonsils, ileocecal valves and brain of all piglets in G1, G2 and G3 immediately after death. The lymphoid tissue specimens were fixed $48 \mathrm{~h}$ in $10 \%$ buffered formalin, $\mathrm{pH} 7.4$. The brain was cut the coronal sections, on brain slabs $2-4 \mathrm{~mm}$ according to standardized procedure, starting at the frontal lobe and ending in the medulla oblongata. After this procedure the brain slabs were fixed $96 \mathrm{~h}$ in $10 \%$ buffered formalin, $\mathrm{pH}$ 7.4. The samples were dehydrated through a graded series of alcohol and xylen and embedded in paraffin by routine technique for light microscopy. Paraffin embedded sections $(4-5 \mu \mathrm{m})$ were stained with haematoxylin and eosin (HE). The immunohistochemical method was applied in order to detect the CSFV glycoprotein E2 (gp55), using the monoclonal antibody WH303 (Veterinary Laboratories Agency, Addlestone, UK). Antigen retrieval method was employed according to the manufacturer procedure and modified by Polacek et al. [5]. Endogenous peroxidase activity was blocked in $0.5 \%$ hydrogen peroxide in methanol (15 minutes) and preincubation was carried out with 50\% normal goat serum (30 minutes). Primary antibody WH303 diluted 1:50 in PBS containing 10\% normal goat serum was incubated for 18 hours at $4^{\circ} \mathrm{C}$ as described by Carassco et al. $[16,17]$. Biotinylated goat anti-mouse immunoglobulin (DAKO, ChemMate, Danmark) was applied as the secondary antibody 20 minutes at $20^{\circ} \mathrm{C}$. Visualisation was achieved with streptavidin-peroxidase complex (DAKO, Danmark) 20 minutes at $20^{\circ} \mathrm{C}$ using 3-3' diaminobenzidine-tetrahydrochloride (DAKO, Liquid DAB, Danmark) and 3-amino-9 etilcarbasole (DAKO, ChemMate, AEC, Danmark). Counterstaining was performed with Mayer's haematoxylin.

\section{RESULTS}

\section{Results of antibody detection in the serum}

In all the tested serum samples of piglets from G1, G2 and G3, the virus neutralization test showed no detection of specific antibodies to Bovine Viral Diarrhoea Virus (BVDV). The results of blocking ELISA test for the detection of anti-CSFV antibodies proved the presence of antibodies in serum samples of piglets in G1 before the challenge. However, there was no presence of anti-CSFV antibodies in the serum of piglets in G2 and G3. 


\section{Results of molecular testing}

The results of RT-PCR test confirm that in the examined tissue samples in all the tested piglets of G1 and G2 groups RNA of CSFV was detected. In the samples of piglets in control group (G3) no RNA of CSFV was detected. Using qualitative PCR reaction the absence of PCV2 infection was proven for each piglet in G1, G2 and G3.

\section{Clinical signs}

All piglets inoculated with CSFV showed clinical signs of CSF. Rectal temperature was between $40.6{ }^{\circ} \mathrm{C}$ and $41.4^{\circ} \mathrm{C}$, $48 \mathrm{~h}$ after inoculation. Reduced appetite and apathy were noticed $72 \mathrm{~h}$ post inoculation. Conjunctivitis was recorded from the $5^{\text {th }}$ day post inoculation (dpi). Yellowish gray diarrhoea was noticed from 7-8 dpi. Neurological sings (convulsions, staggering gait, and posterior paresis) were recorded from 7-14 dpi. Hyperaemia, cyanosis and skin haemorrhages were also noticed from 9 dpi. All experimentally infected piglets in both groups died by the $22^{\text {nd }}$ dpi. The mortality pattern is shown in Table 1. The G1 piglets with maternal immunity had reduced clinical evidence of the disease and clinical signs of lower intensity, appeared a few days later then in non-immune G2 animals. None of the piglets in G3 showed clinical signs of CSFV.

Table 1. Mortality pattern of pigs

\begin{tabular}{ccccccccc}
\hline Group/dpi & 7. & $\mathbf{1 1 .}$ & $\mathbf{1 4 .}$ & $\mathbf{1 6 .}$ & $\mathbf{1 7 .}$ & $\mathbf{1 9 .}$ & $\mathbf{2 1 .}$ & $\mathbf{2 2 .}$ \\
\hline G1 & 1 & 1 & 2 & 1 & 1 & 0 & 1 & 1 \\
G2 & 1 & 1 & 1 & 2 & 0 & 1 & 0 & 2 \\
\hline
\end{tabular}

\section{Gross lesions}

Tonsils. The most common finding in G1 was mild hyperaemia of tonsils and petechial haemorrhages in the epiglottis (Figure 1A). Hemorrhages and necrotic changes on tonsils of various degree were the prominent findings. Necrotic changes ranged from discrete in G1 (Figure 1B), to massive with necrotic deposits which completely covered the surface of the tonsils in G2 (Figure 1C). The mandibular lymph nodes were swollen and enlarged with a characteristic marbled appearance in cross-section (Figure 1B) and with subcapsular to diffuse haemorrhages. Mandibular lymph nodes of G1 and G2 piglets were enlarged, hyperaemic, with haemorrhages of different intensity. There were subcapsular haemorrhages on cross sections of the mandibular lymph nodes (Figure 1A), while in most cases the middle part of mandibular lymph nodes resembled fat tissue, sometimes with petechial haemorrhages (Figure 1C). Ileocecal valves and surrounding tissue in all G1 and G2 animals were covered with grey-yellow to green-yellow deposits, which were difficult to remove. The crypts were filled with massive necrotic detritus in G2 (Figure 3A). Dilatation of crypts filled with necrotic detritus is a common macroscopic finding on the cross section of ileocecal tonsil in both 
G1 and G2 groups (Figure 3B, 3C). Brain. Gross lesions in the brain of piglets of G1 and G2 were in conjunction with the level of recorded neurological clinical signs. Dilatation of blood vessels in leptomeninges, haemorrhages in cerebellum, brainstem and mid-brain were found in piglets of both G1 and G2 group (Figure 4A, 4B, 4C). There were no gross lesions in the tonsills, mandibular lymph nodes, ileocecal valves and brain in the piglets of G3.

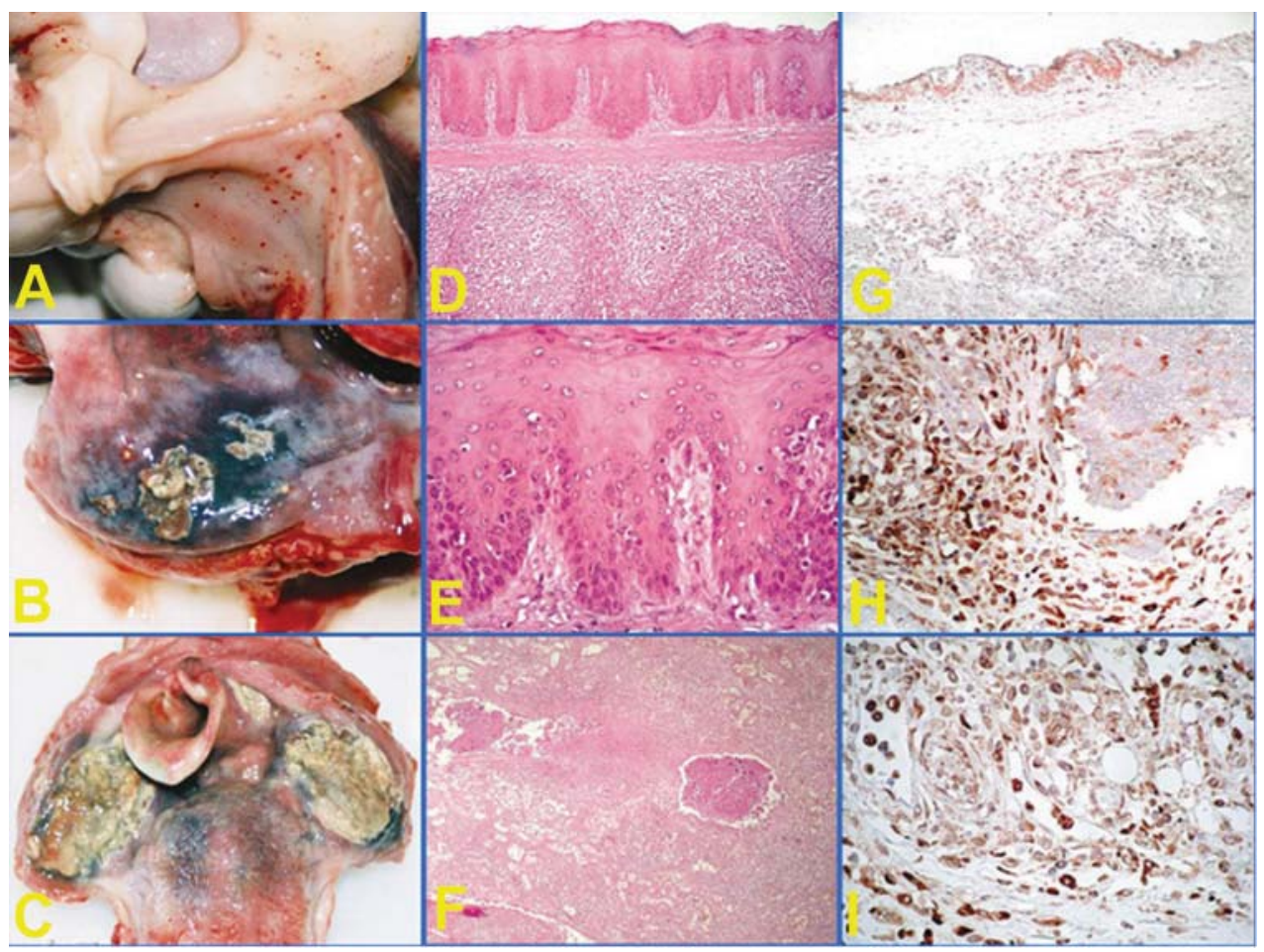

Figure 1. Tonsils in experimentally infected pigs

A-macroscopic lesions in tonsils and epiglottis, G1, 7. dpi; B-macroscopic lesions in tonsils, G2, 17. dpi; C-massive necrotic deposits on tonsils, G1, 14. dpi; D-Tonsil, proliferation of epithelium, G2, 14. dpi, HE, x200; E-Tonsil, proliferation of epithelium G2, 14. dpi, HE, x400; F-Tonsil, necrotic lymph follicles, G2, 16. dpi, HE, x100; G-Tonsil, G1, 14. dpi, expression of E2 protein of the CSFV, WH303, LSAB, x200; H-Tonsil, G2, 22. dpi, expression of E2 protein of the CSFV, WH303, LSAB, x200; I-Tonsil, G2, 22. dpi, expression of E2 protein of the CSFV, WH303, LSAB, $\mathrm{x} 400$.

\section{Histopathology}

Tonsils. Proliferation of the epithelial cells of tonsil crypts (Figure 1E), necrosis in the epithelium, as well as enlarged and partially necrotic lymph follicles (Figure 1D, $1 \mathrm{~F}$ ) were a very frequent finding in all infected pigs. All described changes have been accompanied by haemorrhages. Mandibular lymph nodes. Diffuse haemorrhages 
are a very frequent finding in mandibular lymph nodes of G1 and G2 pigs that were infected with CSFV (Figure 2D). Sinuses were remarkably dilated, often with numerous erythrocytes and macrophages. Lymphocyte depletion, as well as blood vessels degeneration and thrombosis, were found in a few samples of G2 pigs (Figure $2 \mathrm{E}, 2 \mathrm{~F}$ ). Ileocecal valve. Cystic gland lumen was filled with necrotic detritus (Figure 3D). In pigs of groups G1 and G2, the walls of blood vessels were changed by hyaline degeneration and a fine fibrin net was found in the lumen of some blood vessels (Figure 3E, 3F). Brain. Microscopic changes in the samples of brain tissue had a characteristic of non-purulent meningo-encephalitis. A swelling with intense dilatation of blood vessels, haemorrhages and perivascular mononuclear cell infiltration was found in the leptomeninges of cerebellum in G2 piglets (Figure 4D, 4E). Endothelial cells swelling and haemorrhages in the brain parenchyma were present, as well (Figure 4F). Degenerative changes were also spotted on some neurons. (Figure 4E).

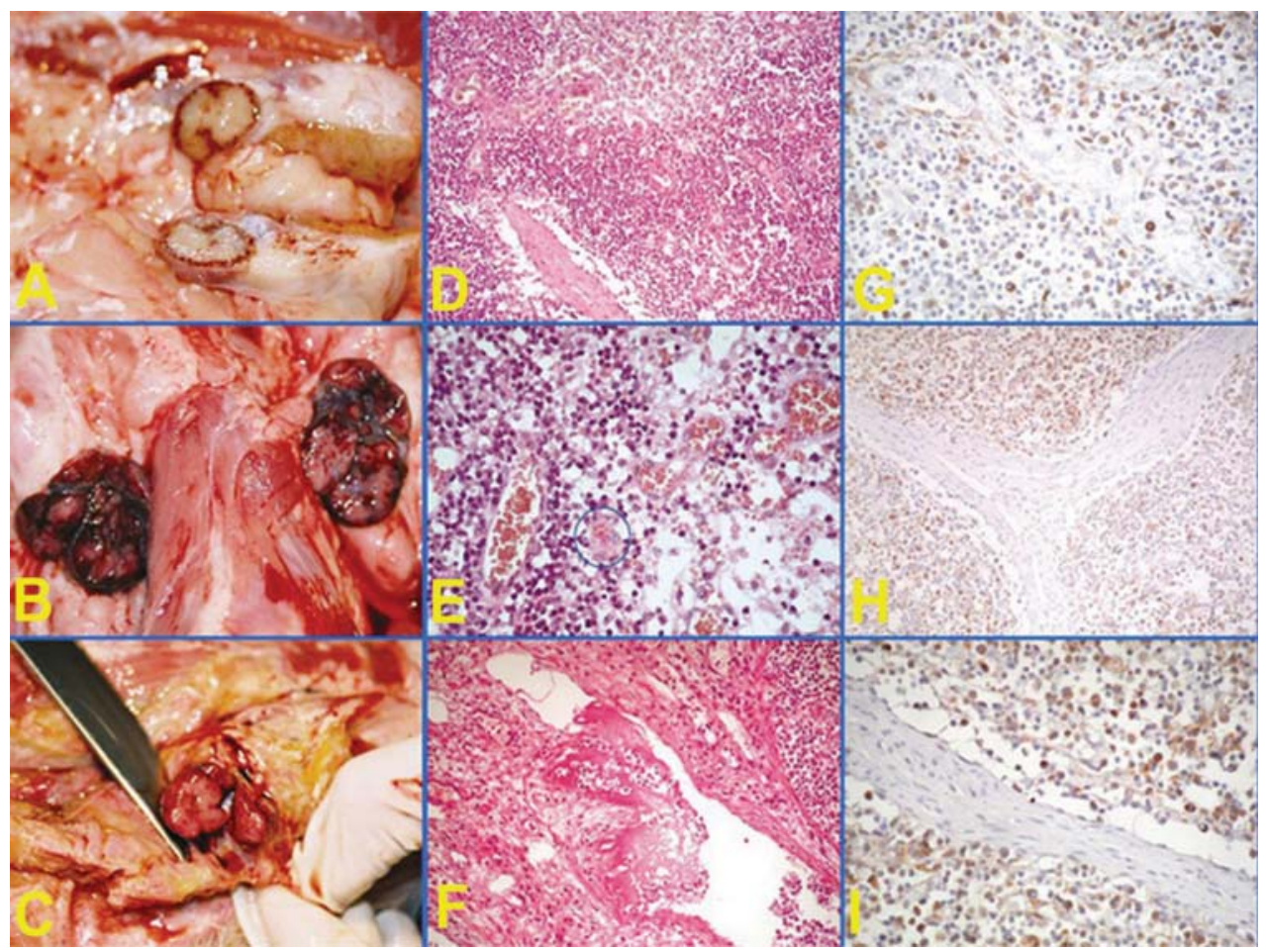

\section{Figure 2. Mandibular lymph nodes in experimentally infected pigs}

A-Mandibular lymph node, cross-section, G2, 16. dpi; B-Mandibular lymph node, cross section, G2, 22. dpi; C- Mandibular lymph node, cross-section, G1, 11. dpi; D-Mandibular lymph node, G1, 7. dpi, HE, x100; E-Mandibular lymph node, G1, 7. dpi, HE, x200; F-Mandibular lymph node, G1, 14. dpi, HE, x200; G-Mandibular lymph node, G2, 16. dpi; expression of E2 protein of the CSFV, WH303, LSAB, x200; H-Mandibular lymph node, G1, 11. dpi; expression of E2 protein of the CSFV, WH303, LSAB, x400; I-Mandibular lymph node, G1, 11. dpi; expression of $\mathrm{E} 2$ protein of the CSFV, WH303, LSAB, $\mathrm{x} 400$. 


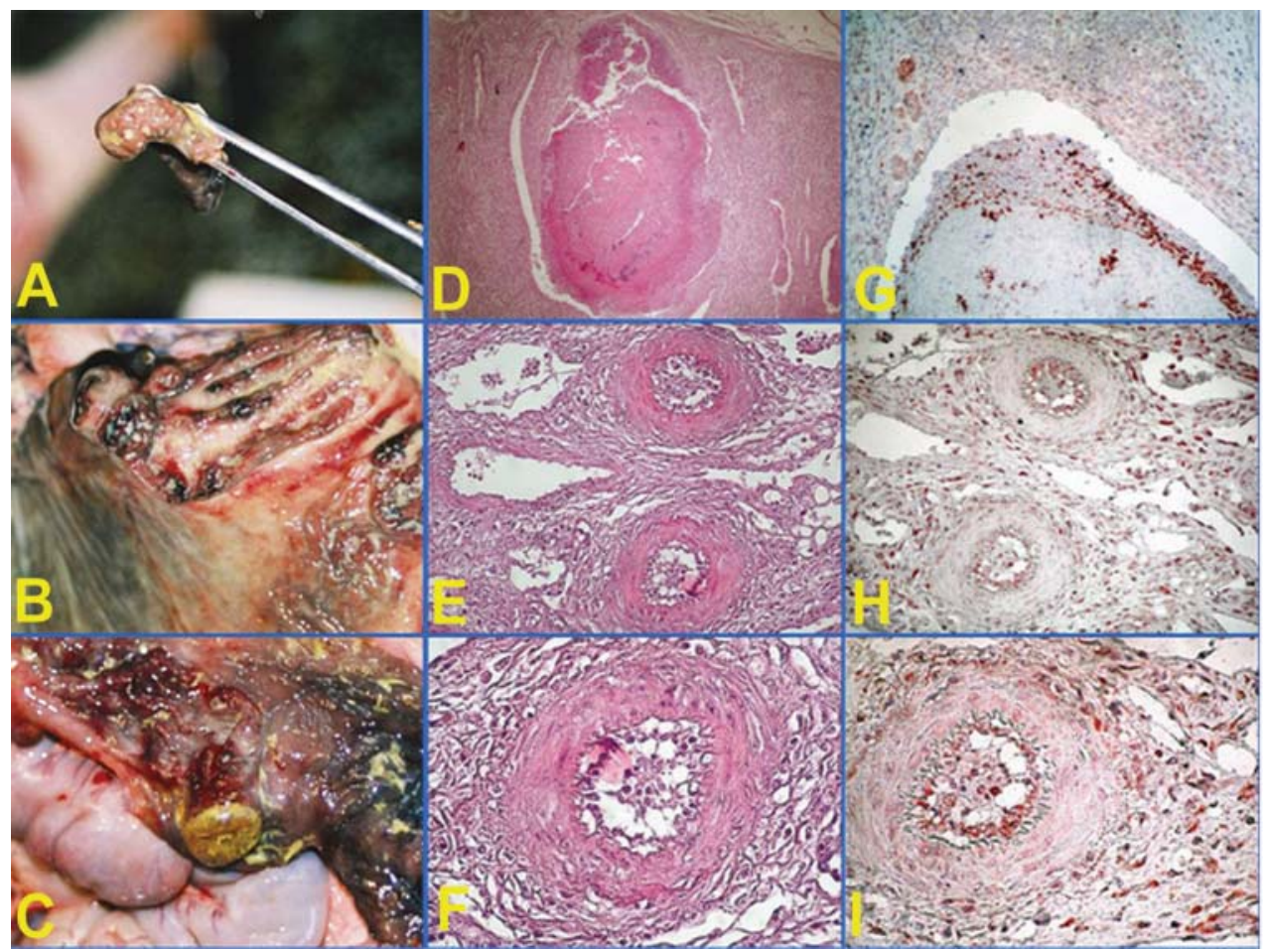

Figure 3. Ileocecalvalves in experimentally infected pigs

A-Ileocecal valve, G1, 14. dpi; B-Ileocecal valve, G2, 22. dpi; C-Ileocecal valve, G1, 16. dpi; D-Ileocecal valve, G1, 11. dpi, HE, x40; E-Ileocecal valve, G1, 22. dpi, HE, x200; F-Ileocecal valve, G1, 22. dpi, HE, x400; G-Ileocecal valve, G2, 14. dpi, expression of E2 protein of the CSFV, WH303, LSAB, x200; H-Ileocecal valve, G2, 22. dpi, expression of E2 protein of the CSFV, WH303, LSAB, x200. I-Ileocecal valve, G2, 22. dpi, expression of E2 protein of the CSFV, WH303, LSAB, $x 400$.

There was no evidence of differences in microscopical findings in the lymphoid tissues as well as in the brain, regarding different time of piglets death, within both G1 and G2. There were no detected histopathologycal lesions in the tonsills, mandibular lymph nodes, ileocecal valves and brain of the piglets of G3.

\section{Detection of E2 (gp55) antigen of CSFV}

Tonsils. A positive reaction on the presence of E2 protein (gp55) of CSFV was found in tonsils of G1 and G2 piglets in the tonsil epithelium and tonsil crypts epithelium (Figure 1G). The expression of E2 glycoprotein was determined in inter-follicular and follicular lymphocytes and macrophages. Very intensive positive reaction on CSFV was present in endothelial cells of blood vessels as well as in the intravascular macrophages in G2 (Figure 1H, 1I) and in the cellular infiltrate surrounding blood vessels. Mandibular lymph nodes. The cells positive to E2 protein (gp55) were distributed diffusely in the parenchyma of mandibular lymph nodes. The largest number of positive cells 
surrounded sinuses (Figure 2G) and were also present in their lumina (Figure 2H). Macrophages, lymphocytes and plasma cells, as well as endothelial blood vessel cells and intravascular macrophages expressed E2 glycoprotein of CSFV (Figure 2I) in both groups G1 and G2. Ileocecal valve. An intense expression of E2 glycoprotein of CSFV was found in the ileocecal valves of all infected pigs of G1 and G2. Epithelial cells of ileocecal valve crypts and cells in the necrotic detritus in the very lumen of these crypts revealed a positive reaction (Figure 3G). Positively stained intravascular macrophages and other cells trapped within the fibrin net were found in the lumen of blood vessels (3H, 3I). Brain. The most intense expression of E2 glycoprotein of CSFV was detected in the leptomeninges. Endothelial cells of leptomeningeal blood vessels, as well as intravascular macrophages also expressed a positive reaction (Figure $4 \mathrm{G}, 4 \mathrm{I})$. In one case of $\mathrm{G} 2$, expression of $\mathrm{E} 2$ in the parenchyma of the cerebellum was recorded and it is obvious that the positive cells have morphological characteristics of macrophages (Figure 4H). There was no detection of E2 protein (gp55) of CSFV in the tonsills, mandibular lymph nodes, ileocecal valves and brain of the piglets of G3.

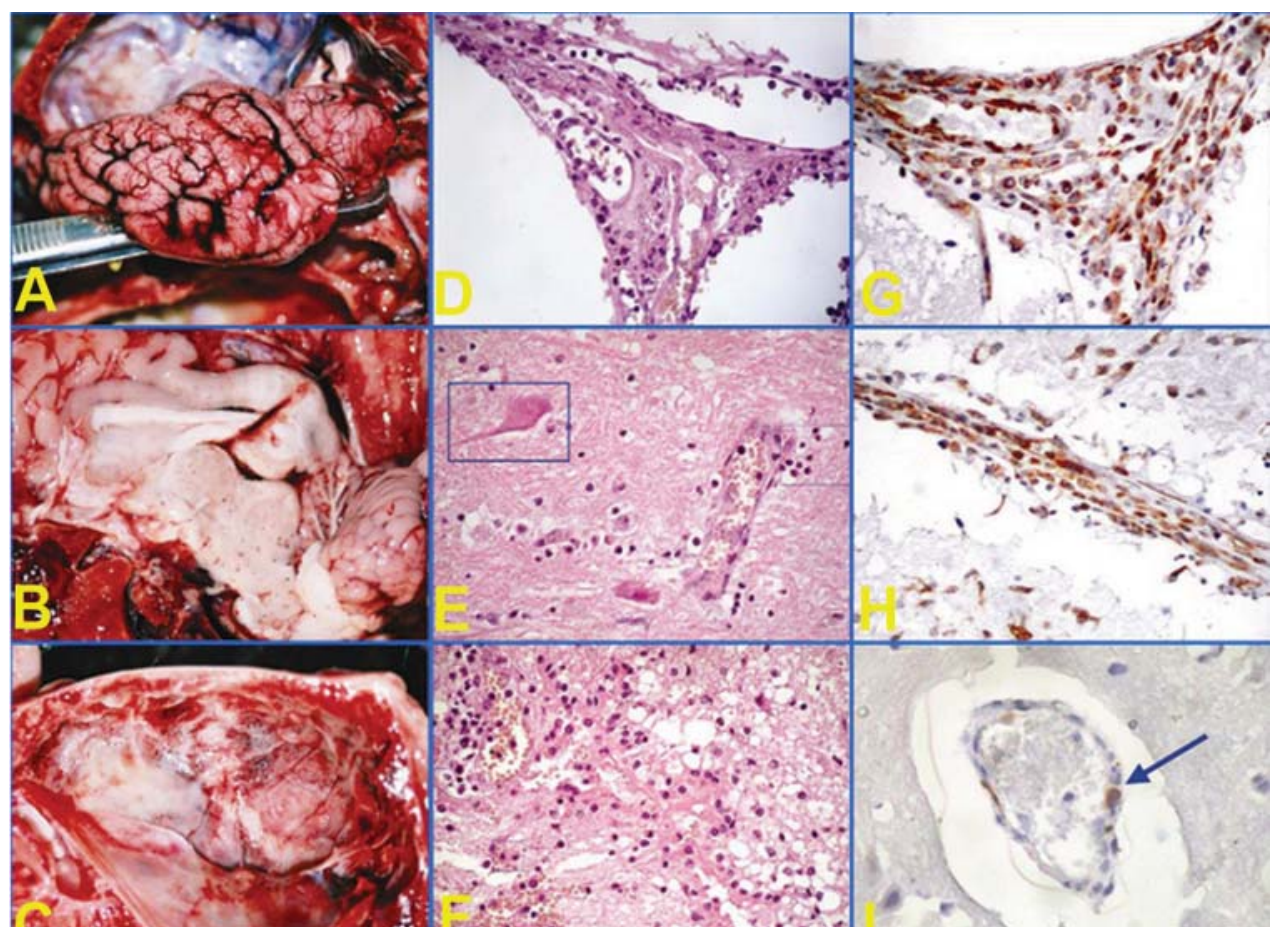

Figure 4. Brain in experimentally infected pigs

A-Brain, G1, 11. dpi; B-Brain, G2, 22. dpi;C-Brain, G2, 16. dpi; D-Leptomeninges, G1, 11. dpi, HE, x400; E-Brain, G2, 19. dpi, HE, x200; F-Brain, G2, 19. dpi, HE, x200; G-Brain, G1, 11. dpi, expression of E2 protein of the CSFV, WH303, LSAB, x400; H-Brain, G1, 11. dpi, expression of E2 protein of the CSFV, WH303, LSAB, x200; I-Brain, G2, 14. dpi, expression of $\mathrm{E} 2$ protein of the CSFV, WH303, LSAB, $\mathrm{x} 400$. 


\section{DISCUSSION}

Classical swine fever is a highly contagious disease of swine which occurs around the world $[1,3]$. In the current study, we found differences in the severity of lesions in the lymphoid tissue and brain between the piglets that originate from vaccinated and unvaccinated sows. Despite the differences in lesion severity, the level of colostral antibodies was able to reduce the clinical signs, but not to protect the piglets from the fatal outcome of the disease. Among others, this finding may also have impact on vaccination policy in the future. Having all the aforementioned in mind and the fact that the last CSF outbreak in Serbia was in 2010 [17], and vaccination of all domestic pigs with attenuated C-strain is still a mandatory control measure for CSF in Serbia [18], soon non-vaccination policy should be harmonized with EU directives. In the early beginning of the non-vaccination campaign new cases of CSF are expected to occur.

In the present study, all piglets with (G1) or without (G2) maternal immunity, intramuscularly inoculated with $2 \times 10^{5} \mathrm{TCDI} /{ }_{50}$ of CSFV, Baker strain, succumbed to the disease with characteristic clinical and morphological signs of CSF. However, we found that the microscopic examination was the most useful method to investigate the differences and morphological nature of the disease between these two groups. Previously it was demonstrated that the monocytes and immature granulocytes, as well as vascular endothelial cells are the main cell populations infected with the virus, consequently leading to the damage of various tissues $[11,16]$. Considering the role of monocyte/macrophage cells lineage, secretion of cytokines was already described in details in CSFV infected pigs [10]. The presence of viral antigens is necessary to induce TNF-expression, the cytokine involved in the inflammatory response and its role is connected with the induction of apoptosis. Recently, the expression of CSFV antigens was demonstrated also in dendritic cells [17]. However, the intensity of the both, tissue lesions in the brain as well as lymphocyte depletion in lymphoid organs, depend on the virulence of the virus [12].

Results of IHC and RT-PCR revealed the presence of CSFV in lymphoid and brain tissue. Furthermore, immunohistochemistry confirmed not only the presence, but also the distribution of CSFV in the tested tissue samples: tonsils, mandibular lymph nodes, ileocecal valves and brain. The most prominent microscopic lesion that we found in lymphoid tissue was lymphocyte depletion, which was described in studies of other authors, as well $[12,19,20]$. In an earlier study we also described the changes that were developed in mandibular lymph nodes in the spot of massive depletion of CD3 and CD79 lymphocytes during experimental infection of pigs with CSFV [5]. Since in our experiments maternally immune piglets had clinical evidence of the disease a few days later then non-immune animals, we assume that passively transferred antibodies neutralized the virus to a certain level but it was not able to prevent the fatal outcome of the disease. In addition to lymphocyte depletion, circumscript necrosis "buttons" in the ileocecal valve was determined by histological examinations 10-12 days after 
challenge. The results of this study demonstrate also detection of E2 (gp55) antigen in the brain, indicating that CSFV is localized in endothelial cells of blood vessels, as well as in mononuclear infiltrate in the leptomeninges of the cerebellum. These results were obtained in our study mostly in piglets of G2, without maternal antiCSFV antibodies. However, our results also confirmed the lack of expression of E2 (gp55) of CSFV in neurons. At the same time we found a low intensity of expression of $\mathrm{E} 2$ ( $\mathrm{gp} 55)$ in brain tissue samples from the piglets of $\mathrm{G} 1$ originated from vaccinated sows. In this group, the E2 (gp55) virus antigen was found in the brain only in some endothelial cells in small blood vessels.

One study reported the localization of E2 (gp55) antigen in the inflammatory perivascular infiltrate in the cerebellum and in choroid plexus epithelium. However, similar to our results, the authors have not found expression of E2 (gp55) antigen in neurons [19].

Although ELISA can only detect the presence of antibodies it was obvious that the amount of colostral anti-CSFV antibodies in the blood of infected piglets, originating from vaccinated sows, was below the protection level [18]. Various influences which could impact colostral immunity were already described [21,22,23]. The current study showed that the IHC technique is a useful tool for detection, localisation and distribution of CSFV in formalin fixed, paraffin embedded tissue samples. We found differences in the severity of histological lesions, in the lymphoid tissue and the brain between the piglets with and without maternal immunity. Despite the differences in lesion severity, protection of the piglets with the present level of colostral antibodies was not enough to prevent a fatal outcome of the disease. This observation was not unexpected since it was demonstrated that this level of colostral CSFV antibodies was only sufficient to reduce the clinical signs of CSF in the first four weeks of life, in pigs originating from vaccinated sows [18].

\section{Acknowledgement}

This study was supported by Project III 46002 and TR 31071 of Ministry of Education, Science and Technological Development, Republic of Serbia.

\section{REFERENCES}

1. Van Oirschot JT: Classical Swine Fever (Hog Cholera). In: Diseases of Swine, 8th Edition, Ed. Straw BE, Blackwell Science, 1999.

2. Van Oirschot JT: Vaccinology of swine fever: from lab to field. Vet Microbiol 2003, 96: 367-384.

3. Paton DJ, Greiser-Wilke I: Classical swine fever-an update. Res Vet Sci 2003, 75:169-178.

4. Moennig V: Introduction to classical swine fever: virus, disease and control policy. Vet Microbiol 2000, 73: 93-102. 
5. Polaček V, Prodanov J, Lazić S, Petrović T, Rašić Z, Aleksić-Kovačević S: Immunohistochemical detection of $\mathrm{B}$ and $\mathrm{T}$ lymphocytes in mandibular lymph nodes of experimentally infected piglets with clasical swine fever virus. ActaVet-Beograd 2007, 57(23):199-208.

6. Šuša M, Konig A, Saalmuller A, Reddehase MJ, Thiel HJ: Pathogenesis of Classical swine fever: B-lymphocyte deficiency caused by hog cholera virus. J Viro 1992, 66: 1171-1175.

7. Sato M, Mikami O, Kobayashi M, Nakajima Y: Apoptosis in the lymphatic organs of piglets inoculated with classical swine fever virus. Vet Microbiol 2000, 75: 1-9.

8. Summerfield A, Zingle K, Inumaru S, McCullough MC: Induction of apoptosis in bone marrow neutrophil-lineage cells, by classical swine fever virus. J Gen Virol 2001, 82: 13091318.

9. Sánchez-Cordón PJ, Romanini S, Salguero FJ, Ruiz-Villamor E, Carrasco L, GómezVillamandos JC: Histopathological, immunohistochemical and ultrastructural study of intestine in pigs inculated with Classical swine fever virus. Vet Pathol 2003, 40: 254-262.

10. Sánchez-Cordón PJ, Núñez A, Salguero FJ, Carrasco L, Gómez-Villamandos JC: Evolution of T Lymphocytes and Cytokine Expression in Classical Swine Fever (CSF) Virus Infection. J Comp Pathol 2005, 123: 249-260.

11. Summerfield A, Knotig SM, McCullough MC: Lymphocyte apoptosis during Classical Swine Fever. Implication of activation-induced cell death. J Viro 1998, 72 (2): 1853-1861.

12. Narita M, Kawashima K, Kimura K, Mikami O, Shibahara T, Yamada S, Sakoda Y: Comparative immunohistopathology in pigs infected with highly virulent or less virulent strains of hog cholera virus Vet Pathol 2000, 37: 402-408.

13. Becskei Zs., Aleksić-Kovačević S, Rusvai M, Balka GY, Jakab CS, Petrović T, Knežević M: Distribution of porcine circovirus 2 Cap antigen in the lymphoid tissue of pigs affected by Postweaning Multisystemic Wasting Syndrome. Acta Vet Hung 2010, 58 (4): 483-498.

14. Milićević V, Radojičić S, Valčić AM, Ivović V, Maksimović-Zorić J, Radosavljević V: Detection and genotyping of classical swine fever virus isolates in Serbia. Acta Vet-Beograd 2013, 63(2-3):191-200.

15. Nedić D, Tešić M, Baltić M, Plavšić B, Tajdić Nada, Mirilović M, Rajković M: Management and control program for suppression and eradication of Classical swine fever in Serbia, Acta Vet-Beograd 2011, 61:(2-3), 295-307.

16. Carrasco L, Ruiz-Villamor E, Gómez-Villamandos JC, Bautista MJ, Núñez A, Quezada M, Sierra MA:Atypical cilia in the bronchiolar epithelium of pigs experimentally infected with hog cholera virus, J Comp Path 2001, 124: 29-35.

17. Carrasco CJ, Rigden RC, Vincent IE, Balmelli C,Ceppi M, O.Bauhofer O, Tache V, Hjertner B, McNeilly F, Van Gennip HG, McCullough KC, Summerfield A: Interraction of classical swine fever virus with dendritic cells. J Gen Virol 2004, 85:1633-1641.

18. Prodanov J, Došen R, Pušić I, Bugarski D, Valčić M: Passive immunity evaluation in piglets originating from sows vaccinated with China strain of classical swine fever virus. Acta VetBeograd 2007, 57(5-6): 413-427.

19. Martın de lasMulas, J, Ruiz-Villamor E, Donoso S, Quezada M, Lecocq C, Sierra, MA: Immunohistochemical detection of hog cholera viral glycoprotein 55 in paraffin-embedded tissues. J Vet Diagn Investig 1997, 9:10-16.

20. Narita M, Kimura K, Tanimura N, Ozaki H: Immunohistochemical Detection of Hog Cholera Virus Antigen in Paraffin Wax-embedded Tissues from Naturally Infected Pigs. J Comp Pathol 1999, 121: 283-286. 
21. Wuren M, Yougang Z., Huangrong L, Banchao S., Jiefeng L, Jin Y, Changrong W, Xiaolong X, Yuying H, Xiaoxi L, Fenghua L, Jianqin X: Effect of transport stress on peripheral blood lymphocyte subsets and Th cytokines in pigs. ActaVet-Beograd 2012, 63(2-3):177-190.

22. Šamanc H, Sladojević Ž, Vujanac I, Prodanović R, Kirovski M, Dudovski P, Kirovski D: Relationship Between Growth Of Nursing Pigs And Composition Of Sow Colostrum And Milk From Anterior And Posterior Mammary Glands. Acta Vet-Beograd 2012,63(56): 537-548.

23. Kovačocyová K, Reichel P, Seidel H, Brenesselová M, Kósa B: Influence of beta-glucan and vaccination against Lawsonia intracellularis on selected immune indices in weaned piglets. Acta Vet-Beograd 2014, 64(1): 105-114.

\section{EKSPRESIJA E2 (gp 55) ANTIGENA VIRUSA KLASIČNE KUGE SVINJA U LIMFATIČNOM TKIVU I MOZGU EKSPERIMENTALNO INFICIRANE PRASADI SA RAZLIČITIM IMUNOLOŠKIM STATUSOM}

POLAČEK Vladimir, PRODANOV-RADULOVIĆ Jasna, DOŠEN Radoslav, PETROVIĆ Tamaš, BECSKEI Zsolt, ALEKSIĆ-KOVAČEVIĆ Sanja

Klasična kuga svinja (KKS) predstavlja zarazno oboljenje domaćih i divljih svinja. Cilj ovih ispitivanja bio je utvrđivanje prisustva virusa KKS u uzorcima limfatičnog tkiva i mozga prasadi, poreklom od vakcinisanih i nevakcinisanih krmača, i praćenje intenziteta patoloških promena pri različitom imunološkom statusu. Ispitivanja su izvršena na 20 prasadi oba pola, starosti 45 dana, koja su podeljena u tri grupe (G1, G2 i G3). Prasad G1 grupe poticala su od krmača koje su vakcinisane atenuiranom vakcinom C-soja virusa KKS. Prasad G2 i G3 grupe poticala su od nevakcinisanih krmača. Prasad G3 grupe predstavljala su kontrolnu grupu. Virus KKS inokulisan je intramuskularno prasadima G1 i G2 grupe ("Baker" soj, $2 \times 10^{5}$ TCDI/ ${ }_{50}$ ). Sva prasad su uginula najdalje do 22. dana od momenta inokulacije. Imunohistohemijska metoda je korišćena za dokazivanje E2 (gp55) antigena u uzorcima tonzila, mandibularnih limfnih čvorova, ileocekalnih tonzila i mozga, kod svih prasadi u ogledu. Utvrđena je razlika u intenzitetu patoloških promena u limfatičnom tkivu i mozgu prasadi G1 i G2 grupe. Kolostralna antitela protiv virusa KKS nisu uspela da zaštite prasad od fatalnog ishoda bolesti. Između ostalog, ovi rezultati mogu imati značaj za program vakcinacije u budućnosti. Naime, vakcinacija svinja protiv KKS, atenuiranim K sojem virusa i dalje je obavezna zakonska mera u Srbiji. Uskoro će se program prestanka vakcinacije uskladiti sa EU direktivama. 